Res Publica Revista de Historia de las Ideas Políticas

ISSN: $1131-558 \mathrm{X}$

\title{
Race and the Early American Conservative Movement (1955-1970)*
}

David Sarias Rodríguez**

Recibido: 04-08-2020 / Aceptado: 29-04-2021

Abstract. From its inception with the first number of the magazine of opinion National Review and up to the advent of the Presidency of Richard Nixon the early American conservative movement struggled with the rising tide of civil rights protest and reform. This article examines the correspondence and published primary sources penned by leading members of the American conservative movement so as to offer a comprehensive, chronologically ordered assessment of the evolution of the views on racial inequality offered by the key constituent ideological subcommunities within the American conservative movement: the traditionalists gathered around the pages of National Review, the "neoliberals" led by Milton Friedman y Friedrich von Hayek, the Southern, white conservatives and, lastly, the neoconservatives, which headed by Irving Kristol and Norman Podhoretz articulated much of such views in a manner palatable to a significant segment of the American political mainstream.

Keywords: Conservatism; Neoliberalism; Neoconservatism; Race; Civil Rights.

\section{[es] La cuestión racial y el movimiento conservador estadounidense temprano (1955-1970)}

Resumen. Desde sus orígenes con la aparición del semanario de opinión National Review y hasta el ascenso de Richard Nixon a la presidencia de los Estados Unidos, el movimiento conservador estadounidense temprano se enfrentó a la creciente tensión generada por las tensiones entorno a la cuestión de los derechos civiles. Este artículo examina la correspondencia y la obra publicada de los principales intelectuales y activistas del movimiento conservador temprano para ofrecer, desde ahí, una evaluación completa y cronológicamente ordenada de la evolución de las propuestas raciales preferidas por las subcomunidades ideológicas más relevantes dentro del movimiento conservador: desde los propios conservadores sureños blancos, pasando por los traidicionalistas de National Review liderados por William F. Buckley y Russell Kirk, los "neoliberales" encabezados por Milton Friedman y Friedrich von Hayek para culminar, por ultimo, en la aportación de los neoconservadores liderados por Irving Kristol y Norman Podhoretz y mediante la cual ciertos elementos centrales del canon conservador en cuestiones raciales lograron adquirir respetabilidad política e intelectual en Estados Unidos.

Palabras clave: conservadurismo; neoliberalismo; neoconservadores; cuestión racial; derechos civiles.

Sumario. 1. The Conservative Movement and racial inequality. 2. Intra-conservative conflict and adjustment. 3. Conclusions. 4. Sources. Cited bibliography.

Cómo citar: Sarias Rodríguez, D. (2021). Race and the Early American Conservative Movement (1955-1970). Res Publica. Revista de Historia de las Ideas Politicas, 24(2), 223-235.

Between 1955, the year that the seminal conservative journal National Review was first published and the 1968 elections, when Richard Nixon reached the White House, American politics witnessed the emergence both of increasing civil rights mobilisation and of the early conservative movement. This article examines the views of the latter upon the former. The
American conservative movement is seen in these pages as an epistemic community gathering intellectuals and activists who, in turn, belonged to six distinct sub-groups, rather than the standard approach first proposed by George Nash's influential work which approached it as a three winged movement split between libertarians, traditionalist conservatives and anticom-

\footnotetext{
* Research for this article was funded by the Department of History of the University of Sheffield, The Royal Historical Society, The Gilder Lehrman Institute for American History and the Gerald Ford Presidential Foundation.

** Universidad Rey Juan Carlos

david.sarias@urjc.es
} 
munists ${ }^{1}$. The perspective taken here affords a different insight over the evolution of American conservatism on two accounts. First, it facilitates a holistic assessment of the racial views put forth by conservatism as a diverse but cohesive movement that goes beyond existing published work focused on evaluations of only one single group such as Southern segregationists or the intellectuals at the journal National Review or particular individuals such as the Review's editor and leading conservative activist William F. Buckley or the infamous North Carolina senator Strom Thurmond ${ }^{2}$. Secondly, this approach, which is conducted through the examination of archival material, published memoirs and interviews conducted by the author, allows for more comprehensive and refined evaluation of the role placed by race within intra-conservative relationships until the conservative canon on racial issues filtered into the American political mainstream.

This analysis excludes conservative sub-families that played a minor role in the formation of a conservative view over racial conflicts, such as the technocratic minded right-wingers gathered around the American Enterprise Institute; it also excludes later incorporations to the movement such as the Christian right which had a significant role indeed in debates about race but only emerged after the second half of the 1970s. It also builds on Nash's much valued (and valuable) contributions in the sense that his book was very much focused on the evolution of the "hardcore" conservatism of National Review and on an assessment of the American Conservative Movement as a three-pronged epistemic community made up of libertarians, traditionalists and anticommunists, held together by anticommunism. These pages focus instead in an examination of the approach to race of the four constituent groups of the early American conservative movement which were active and had a significant impact on the building of the conservative narrative over the racial affairs of the United States during the period assessed. Firstly, the movement as a whole was, as Nash and other have consistently noted, led during those years by the National Review or 'hard core' group,

G. H. Nash, The Conservative Intellectual Movement in America Since 1945, Wilmington DE, Intercollegiate Studies Institute, 1998 , p. Xv. Nash's views are consistently repeated in every book surveying the post-war conservative movement in the United States, cf. for instance G. Hodgson, The World Turned Right Side Up, A History of the Conservative Ascendancy in America, Boston, Houghton Mifflin, 1996, pp. 44-45, 51; J. L. Himmelstein, To The Right, The Transformation of American Conservatism, Berkeley, University of California Press, 1990, pp. 49-60; S. Diamond, Roads To Dominion, RightWing Movements and Political Power in the United States, New York, Guilford Publications, 1995, pp. 29-35; J. Micklethwait and A. Wooldridge, The Right Nation, Conservative Power in America, New York, Penguin, 2004, p. 51; M. Schaller, Right Turn, American Life in the Reagan-Bush Era, New York, Oxford University Press, 2007, pp. 4-6; J. Hardisty, Mobilizing Resentment, Conservative Resurgence from the John Birch Society to the Promise Keepers, Boston, Beacon Press, 1999, pp. 39-40; L. Edwards, The Conservative Revolution, The Movement that Remade America, New York, Free Press, 1999, pp. 78-79.

2 Cf. for instance J. B. Judis, William F. Buckley, Patron Saint of the Conservatives, New York, Simon \& Schuster, 1988; J. Bass and M.W. Thompson, Ol'Strom, The Unauthorised Biography of Strom Thurmond, Marietta GA, Longstreet, 1998, pp. 111-12; N. Cohodas, Strom Thurmond and The Politics of Southern Change, New York, Simon \& Schuster, 1993. gathered around the eponymous journal which began to be published in 1955 under the editorship of William F. Buckley (hence also the label "buckleyite" conservatives) and focused on a vigorous defence of what they identified as "traditional" values ${ }^{3}$.

Added to this, sometimes overlapping with it and quite frequently holding vigorous disputations with those self-proclaimed "trationalists", operated a group most precisely defined as neoclassical liberals (usually shorthanded as "neoliberal") or, in American parlance, "libertarians", under the leadership of activists, intellectuals and economists such as Milton Friedman, Firedrich von Hayek and Murray Rothbard. This group was ideologically anchored around the defence of free markets and the type of individual freedom that they associated with $18^{\text {th }}$ and $19^{\text {th }}$ century, "Whig" style, classical liberalism, these pages emphasise the different approaches taken by these two groups, how the diverged and how they mutually reinforced each other's racial stands ${ }^{4}$. This approach allows for a more nuanced examination of the complex relationship between libertarians and traditionalists, for although both groups frequently indulged in dismissing the civil rights movement as a mere communist plot their shared opposition distils the shared proactive, ideological and moral principles - notably a vigorous defence of inequality and hostility to progressive liberalism, rather than communism- different form and ultimately more important than reactive anti-communism.

In third place and starting during the second half of the 1960s a third group of up until then progressive intellectuals hitherto associated to both the Democratic party and liberal (in the American sense of the word meaning "progressive") politics who would later fall under the epithet "neoconservatives" also incorporated themselves to the American conservative community if not quite to the movement led by National Review .

G. H. Nash, op. cit., pp. 24-25, 127-28; A. J. Reichley, Conservatives in an Age of Change, The Nixon and Ford Administration, Washington DC, Brookings Institution, 1981, pp. 22-26; D. W. Reinhard, The Republican Right Since 1945, Lexington KY, University Press of Kentucky, 1983, pp. 5-9; W. F. Buckley, Miles Gone By, A Literary Autobiography, Washington DC, Regnery, 2004, pp. 57-94.

As quoted in The reference to the British, $19^{\text {th }}$ century Whigs was famously made by Friedrich von Hayek in the post-script to his seminal F. Hayek, The Constitution of Liberty, Chicaco, Chicago University Press, 1962; cf. Nash, op. cit., pp. 24-25, 127-28. Some crucial primary sources tracing the divide between libertarians and traditionalists within the American conservative movement in Whittaker Chambers "Big Sister is Watching You", NR, December 28, 1957; Murray Rothbard to William F. Buckley, September 18, 1958, f. Roberts-Royo, box 7, William F. Buckley Jr. papers, Manuscripts and Archives, Yale University Library, New Haven, CT., hereafter WFB papers; Buckley to Rothbard, April 7, 1960, f. Rothbard, box 11 , ibid. For further details on the neoclassical liberal thought and political action cf. N. Bosanquet, After the New Right, London, Heinemann, 1983; R. Cockett, Thinking the Unthinkable: Think Tanks and the Economic Counter-Revolution, London, HarperCollins, 1994; J. Burns, Goddess of the Market, Ayn Rand and the American Right, Oxford, Oxford University Press, 2009.

Neconservatism has spawned its very own historiography that, tellingly enough, tends to be separate and independent from that of the early conservative movement cf. J. Ehrman, The Rise of Neoconservatism, New Haven, Yale University Press, 1995; P. Steinfels, The Neoconservatives, The Men Who Are Changing America's Politics, New York, Simon \& Schuster, 1979; J. Heilbrunn, They Knew They Were Right, The Rise of the Neocons, New York, Anchor Books, 2009; S. A. Halper and J. Clarke, America Alone, The Neo-Conservatives and the Global Order, Cambridge, Cambridge University 
Neoconservatism was, during the period assessed here, a community still in formation both as a cohesive group and as a subfamily within American conservatism. Yet, although neoconservatives were still operating on the margins of the conservative movement they played a crucial role: their longstanding affiliation within liberal intellectual and policy-making circles allowed them to synthesize and update the conservative canon on race in a fashion that took hostility to further civil rights advances closer to the American political mainstream ${ }^{6}$.

Last but not least, Southern conservatives made up a fourth conservative sub-community. In ideological terms, these men built their outlook explicitly around race and the defence of the identity, interests, cultural assumptions and policy practices preferred by white, Southern conservatives and which in those years were focused on the preservation of a racially segregated society in which African Americans retained an openly subordinated role as reflected in both the legal codes and cultural practices of the "Jim Crow" South". This group

Press, 2004, pp. 14, 47; M. Gerson, The Neoconservative Vision, From the Cold War to the Culture Wars, Lanham ML, Madison Books, 1996; G. Hodgson, The Gentleman from New York, Daniel Patrick Moynihan, A Biography, Boston, Houghton Mifflin, 2000. $\mathrm{Cf}$. also a recent re-evaluation in D. Sarias Rodriguez, "The Other 1960s: Re-Assessing the Enduring Influence of Neoconservatism", Revista de Estudios Norteamericanos N. 23, 2019, pp. 271-296. As far as published primary sources cf. the crucial I. Kristol, Neoconservatism, The Autobiography of an Idea, New York, The Free Press, 1995; N. Podhoretz, Commentary Reader, London, Rupert Hart-Davis, 1968, pp. 376-77; ibidem, Breaking Ranks, New York, 1979; D. P. Moynihan, Coping, Essays on the Practice of Government, New York, Random House, 1973.

The predominant view espoused by the bulk of the academic literature (cf. ft. 1 above) has been persuasively challenged along lines not entirely dissimilar from those of this article in J. A. Hijiya, "The Conservative 1960s", Journal of American Studies, 37, no. 2, 2003 , pp. 201-27, especially pp. 214-18. Hijiya's analysis has been partially answered according to more orthodox assumptions in S. Scanlon, "The Conservative Lobby and Nixon's «Peace with Honor» in Vietnam", ibidem, 43, no. 2, 2009, pp. 255-76, particularly p. 259, footnote 6 . A further and excellent piece of work that stands out from the standard reading and is also remarkably similar to these pages may also be found in R. H. King, "The Struggle Against Equality: Conservative Intellectuals in The Civil Rights Era", in T. Ownby, The Role of ideas in The Civil Rights South, Jackson, Mississippi University Press, 2002, pp. 113-136. The difference between these pages and King's work are, however, substantial. The present work does, distinctly, set the neoliberal and neoconservative approach to civil rights quite apart from the traditionalist perspective in the sense that neoliberalism located itself (and was very much located by traditionalist conservatives) squarely within the modern political culture whereas, as King correctly notes, virtually all traditionalist conservatives set themselves against that political culture. King holds that the conservative movement was made up of "antimoderns all". This is central to understand the considerable success enjoyed during the period analysed by neoliberal views that set Lockean notions of individual liberty against federally enforced racial equality legislation in general and integration laws in particular. The author acknowledges Reviewer \#2's suggestion to consult King's work for this article. Again, Southern conservatism has its own body of literature which is only tangentially connected to the literature about either the conservative movement or neoconservatism. Cf. D. A. Horowitz, "White Southerners Alienation and Civil Rights, The Response to Corporate Liberalism", Journal of Southern History 54, May 1988, pp.173200; T. Badger, "Southerners Who Refused to Sign the Southern Manifesto", Historical Journal 42 ,1999, pp. 517-34. N. V. Bartley and H. Graham, Southern Politics and the Second Reconstruction, Baltimore, Johns Hopkins University Press, 1975; N.V. Bartley, The New South, 1945-1980, The Story of the South's Modernization, Baton Rouge, Louisiana State University Press, 1995; E. Black and M. Black, The Rise of Southern Republicans, Cambridge MA, Harvard University Press, 2002; R. Sanders, "Rassling a Governor, Defiance, Desegregation, Claude Kirk, and the Politics of Richard Nixon's was enormously significant because, unlike the rest of the conservative family, these Southerners included a significant contingent of professional politicians and elected officials with considerable influence on the US Congress (notably the Senate) and with a correspondingly significant base of grassroots support. They also made up the mainstay of the conservative's take on the racial affairs of the whole (not only the South's) nation. In the end, as has been told elsewhere, conservatism modified their support for segregation when these leaders shifted their electoral and political strategy with the considerable assistance of both neoconservatism and the Nixon administration ${ }^{8}$.

In effect, the conservatism led by National Review attempted to provide what they regarded as a respectable argument in defence of segregation in the South, and in the process helped to secure the position of Southern political conservatives within the broader conservative communit. Neoconservatives, on their part, took that effort, and rather successfully, from conservatism into the American mainstream. With the accession of the aforementioned Southerners to the conservative movement, the conservative cause would also acquire a relatively large popular constituency in the South, a region which until the late 1940s had been solidly aligned with the Democratic party and certain aspects of Roosevelt's liberal-progressive New Deal. Later on, racial tensions also helped to propel the neoconservatives away from the liberal consensus. Espousing, even indirectly as in the case of the liberarians and the neocons, the cause of Southern segregation and of racially loaded narratives generally, however, triggered two less welcomed effects for the movement as a whole. Firstly, it tarnished conservatism with the stain of racist reaction at a time when conservatives were consciously struggling to achieve ideological respectability. Furthermore, the intellectual leadership's stance on race exacerbated the ever-present tension between the different constituent parts of the conservative movement.

\section{The Conservative Movement and racial inequality}

Throughout the 1950s and early 1960s, the Southern white conservative political leadership had developed a close relationship with the intellectuals who, through the pages of publications such as National Review and Human Events, or organisations like the American

Southern Strategy", Florida Historical Quarterly, 80, no. 3, 2002; D. Carter, The Politics of Rage, George Wallace, The Origins of New Conservatism and The Transformation of American Politics, New York, Simon \& Schuster, 1995. For a brilliant exception cf. M. Lassiter, The Silent Majority, Suburban Politics in the Sunbelt South, Princeton, Princeton University Press, 2006; P. B. Murphy, The Rebuke of Histor. The Southern Agrarians and American Conservative Thought, Chapel Hill, University of South Carolina Press, 2001.

Cf. D. Sarias Rodríguez, "Richard Nixon, las primarias republicanas de 1968 y la modernización del conservadurismo sureño", Historia y Política, Ideas, Procesos y Movimientos sociales, $\mathrm{N}^{\mathrm{o}} 20,2008,293-$ 312; for a case study of the end of Southern frontal opposition to integration cf. R. Sanders, "Rassling a Governor, Defiance, Desegregation, Claude Kirk, and the Politics of Richard Nixon's Southern Strategy", Florida Historical Quarterly, 80, no. 3, 2002. 
Conservative Union (ACU) and Young Americans for Freedom (YAF), were leading the revival of American conservatism. For instance, following the lead of $\mathrm{Na}$ tional Review and the less sophisticated tabloid Human Events, conservative journals consistently lent space to white Southern intellectuals' and journalists' defences of segregation. Modern Age, the then most significant academic-minded conservative journal under the editorship of the prestigious traditionalist conservative Russell Kirk, incorporated as editorial advisors and contributors Richard Weaver, a well known intellectual champion of the traditional white South, as well as the notorious conservative Southern journalist James Jackson Kilpatrick. Similarly, the New Individualist Review, a libertarian-leaning periodical ostensibly devoted to the defence of individual freedom was published under the co-sponsorship of both the libertarian Milton Friedman and the aforementioned Weaver'. This relationship between conservative Southern traditionalists and the other factions within the conservative community was grounded in a number of shared views regarding race and segregation.

The first lines of the rhetorical defence of segregation peddled by both traditionalists and libertarians was, much like that of Southern conservatives, to flatly deny that there was any "objective basis" to support the claim that the United States (one of the "least racist countries in the world") had any particularly virulent race problem at all and blame the conflict on civil rights activists prone to unlawfulness. Thus, National Review articles and the speeches of leading Southern segregationists such as the infamous and influential North Carolina Senator Strom Thurmond were equally prone to blame the "utter distortions of reality" promoted by criminally-minded civil rights activists for the growing racial violence of the $1960 \mathrm{~s}^{10}$. Similarly, after the 1965 Watts riots, the ACU, then the most influential political organisation of the conservative movement, released a statement blaming the peaceful protests led by Martin Luther King for the explosion of violence. According to the ACU, "«non-violent» protest of necessity leads to total mob action" -noticeably, no word was said about the violence of white mobs ${ }^{11}$. Of course, the criminalisation of civil rights campaigners was reinforced and complemented by the alleged association between African-American activists and international communism. The Washington Report, a newsletter published by an influential anticommunist business group linked with the conservative movement, was quite blunt on this subject: in 1968 it cited five examples of cities and towns

$9 \quad$ R. Weaver, "On Setting the Clock Right", National Review, hereafter $N R$, October 12, 1957; "Roots of Liberal Complacency", ibidem, June 8, 1957; R. Whalen "As the South Sees it", ibidem, February 13, 1969; "Semantics vs. the South", Human Events, February 18, 1960, hereafter HE; J. Helms, "Falsehoods About the South", ibidem, March 11, 1962; "Editorial Advisors", Modern Age, vol. 1, no. 1, summer 1957; "Editorial Advisors", New Individualist Review, April 1961, hereafter NIR.

10 Jeffrey Hart to Lyn Nofzliger, April 8, 1968, f. J. Hart, box 50, WFB papers; William Rusher to William F. Buckley June 21, 1963, f. Negro Question, box 40, ibidem.

11 "ACU Statement of Lawlessness and Riots", undated, circa. August 1965, f. ACU, box 57, Marvin Liebman papers, Hoover Institution, Palo Alto CA, hereafter Liebman papers. in which "the Communist Party or Communist splinter groups had sought actively to inject themselves in legitimate civil rights activities"12. At around the same time National Review itself looked into the issue as well, and denounced the alleged links between "Negro militants in America and subversive guerrillas in Latin America", while noting that "some leaders of the US civil rights movement are responding to directives coming out of Havana"13.

The success of this strategy may be measured by the fact that, after 1969 it filtered no less than into the Nixon White House, when the Justice Department deliberately placed civil rights activists in the same category as common delinquents and the revolutionary left ${ }^{14}$. To be sure, throughout the 1960s the Johnson administration had not shied away from treating civil rights activists as criminals or communists and had accordingly put them under surveillance, but the Nixon White House put that strategy at the heart of its public relations operation, taking it to the national press rather vociferously and in terms much reminiscent of both Southern and National Review conservatives ${ }^{15}$. The Nixon administration, through Vice-President Agnew, peddled the same argument with such enthusiasm that even an aide to George Wallace, the racist governor of Alabama turned racist third-party presidential candidate acknowledged in Battle Line -a Republican newspaper tellingly shifting conservativethat Agnew could (and did) "do a damn good selling job" on Wallace's Southern turf ${ }^{16}$. Thus, conservatives aided white segregationist Southerners in their attempt to reduce the civil rights problem to a matter of public order.

In parallel to the "law and order" and communist subversion lines, during the 1950s and 1960s most conservatives -ranging from traditionalists to libertarian free-marketers through neoconservatives- offered critiques of civil rights legislation and affirmative action on seemingly legalistic grounds based on "strict construction" of the Constitution and an idealised analysis of society as a slow-changing organic structure coupled with negative judgements on government efficacy to effect change ${ }^{17}$. As far as the Buckleyites were concerned, segregation was the product of the South's spontaneous social development: federal interference was not only

12 “Summer, 1968 - Riot or Rebellion?", Washington Report, April 15, 1967.

13 Paul D. Bethel, "Black Power and Red Cuba" NR, September 2, 1968.

14 "Nixon Seeks Conference with Hoover over Disorders", HE, September 21, 1968; "Mardian, The Team Player, The Loyalist in Hiding", Washington Post, July 8, 1973, hereafter WP Interview with Howard Phillips, September 7, 2005, Washington DC.

15 "Soaring Crime Rates", Strom Thurmond Reports to the People, August 30, 1965 and "The Radical Left", Strom Thurmond Reports to the People, May 31, 1965, f. Thurmond, box 313, Group Research Records, Rare Book and Manuscript Library, Columbia University Library, New York City, hereafter GR records; "Dictatorship of Children Around the World", HE, December 5, 1964; L. Brent Bozell, "The Lesson of Cambridge... and Salisbury. Was Violence Necessary?", NR, August 27, 1957.

16 "Wallace Again", The Republican Battle Line, January 1970.

17 Cf. James Jackson Kilpatrick, "Civil Rights and Legal Wrongs", $N R$, September, 10 1963. Thurmond had been considerably less careful during his earlier career, cf. J. Bass and Marilyn, op. cit. pp 111-12; N. Cohodas, Strom Thurmond and The Politics of Southern Change, op. cit., p. 177. 
unconstitutional -it also risked wreaking havoc over the region's social fabric. The most infamous example is provided by a 1957 editorial, in which the magazine articulated its standard line on race. "The South does not deprive the negro of the vote for the sake of depriving him of the vote", it helpfully informed African-Americans. Far from such a thing: disfranchisement reflected the fact that "the White community merely intends to prevail -that's all", on "any issues on which there is a corporate disagreement between Negro and White". Besides, according to the magazine, "the great majority of the Negroes in the South do not vote and do not care to vote, and would not know for what to vote if they could"18.

That stand remained essentially unchanged over the period examined: on the eve of the passage of the 1964 Civil Rights act, National Review's editors continued to harbour "frank reservations about the wisdom" of the Brown decision ${ }^{19}$. As the voice of sober conservatism aimed at acquiring respectability, National Review usually stopped short of more blatant strains of racism although at the same time it did occasionally indulge in "explorations" of the relationship between race and intelligence ${ }^{20}$. Instead, the editors opted for a combination of paternalism and what might be best described as xenophobia. According to this view, Southern blacks possessed a distinct culture that was both alien and inferior to that of whites. Indeed some conservatives considered black culture to be sufficiently foreign to justify their support for the draft on the grounds that "a volunteer army would attract...specifically blacks", and "we don't want to be dependent upon a black army to defend us" ${ }^{21}$. In fact, the Buckleyites articulated a view of African-Americans that was astonishingly close to the one that National Review was applying to the newly-independent African nations during the 1950s and 1960s. Hence, it followed that African-Americans deserved about the same treatment that the British had dispensed to the Kenyans and the French to the Algerians, all in the name of preserving a superior European culture ${ }^{22}$. Subsequently, the editors of National Review reached the "sobering" conclusion that Southern whites were "entitled to prevail" because "for the time being" they were "the advanced race". In both cases it was asserted that "the claims of civilization supersede those of universal suffrage". For conservatives the strength of those claims was limited only by their concern about white violence.

18 "Why the South Must Prevail", NR, July 27, 1957, p. 149.

19 William Rusher to William F. Buckley, June 18, 1963, f. Negro Question, box 40, WFB papers.

20 Ernest Van Den Haag, "Intelligence or Prejudice?", NR, December 1, 1964.

21 Neil McCaffrey to William F. Buckley, January 27, 1969, f. Neil McCaffrey, box 68, WFB papers.

22 For a rare overview of the international dimension of the early conservative movement cf. David Sarias Rodríguez, “"We Are All Europeans»: Towards a Cosmopolitan Understanding of the American Traditionalist Right" en D. Scroop and A. Heath (eds)., Transatlantic Social Politics 1800-Present, New York, Palgrave, 2014. A brief but surprisingly close analysis of the international dimension of the conservative movement's racial views in R. H. King, "The Struggle Against Equality: Conservative Intellectuals in The Civil Rights Era", op. cit., 129-13 The author acknowledges again Reviewer \#2's suggestion to consult King's work for this article.
Hence, according to National Review segregation in the United States should only last "so long as" it contributed to the enlightenment of African-Americans "by humane charitable means", just as white Rhodesians ought to "tamper with the tribal society" only through "example and persuasion" 23 .

Seemingly, National Review conservatives remained entirely oblivious to the fact that Southern "persuasion" -never mind rearguard colonial action- throughout the 1950s and 1960s did involve a good deal of violence. But then, these were men who believed that school segregation below the Mason-Dixon Line "was made essential by the social geography of the South", whereupon "through of no fault of their own, Negro children are markedly different from the well-mannered Negro children" who attended "northern schools" 24 .

The conservative intellectual leadership also integrated the white South's rearguard action against civil rights legislation within a libertarian-based broad opposition to "government interference with the individual" and to the "socialist" tendencies of the Great Society 25. In this sense, a significant portion of the free-market libertarian-leaning wing of the conservative movement played an absolutely crucial role in providing Southern whites with a consistent and seemingly colour-blind argument to sustain segregation that would later on be refined by the neoconservatives: civil rights legislation was equated with ultimately armful and inefficient government regulation. Importantly, although libertarians always remained the subordinated strand within the American conservative movements, their position achieved considerable influence in two specific areas that also happened to be rather impervious to the "states' right's" or cultural arguments peddled by traditionalist minded conservatives: among university students and within the legal community ${ }^{26}$. Many libertarians reached the same conclusions defended by Southern political leaders who, in the 1956 "Southern Manifesto", had denounced the federal "dictatorship" from other end of the conservative ideological spectrum. That stand was quite efficiently abstracted by the New Individualist Review, a prominent libertarian journal. "None can deny

23 “A Clarification”, NR, August 31, 1957, p. 199; "The South's Travail”, National Review Bulletin, March 14, 1960; J. Ashbrook, M. Yergan and R. de Toledano, "Report from Rhodesia. Pointing the way to a Multi-Racial Africa?", undated, circa July 1966, f. ACU, box 58, Liebman papers. This pamphlet was published by the American-African Affairs Association, a paper organization staffed by ACU-related conservatives. For similar arguments in a libertarian medium about both white South Africa and white Rhodesia cf. "The Rhodesian Calumny", NIR, winter 1968; T. Molnar, "South Africa Reconsidered", ibidem, winter 1966. National Review's stand modified towards milder positions later on. For instance, the magazine had always remained quite sympathetic to the travails of white South Africans, yet by the late 1960 s it had accepted the need to reform apartheid, albeit gradually and without the pressure of international economic sanctions. For similar views cf. P. Duignan and L. H. Gann, "White and Black in Africa", NR, January 28, 1961; "Letter from Congo", ibidem, March 25, 1961; Elspeth Huxley, "The Castle of Apartheid", ibidem, August 27, 1968.

24 R. Weaver, "As the South Sees it", NR., February 13, 1960.

25 E. Black and M. Black, op. cit. p. 225; Cohodas, op. cit. pp. 211, 274, 326.

26 C. W. Schmidt "Beyond Backlash: Conservatism and the Civil Rights Movement", American Journal of Legal History, 56, 2016, pp. 182, 190-191. 
that discrimination solely on the basis of race is morally indefensible", it argued. "But the right to discriminate, the right to express a preference in the use of one's property which is at variance with the prevailing majority sentiment is of the very essence of liberty"27. Along very similar lines, the future Nobel laureate and enormously influential economist-cum-intellectual Milton Friedman was particularly candid on the matter. Beginning with the assumption that black Americans had "progressed a good deal since the nineteenth century", he also noted that such a development had occurred "thanks to market mechanisms", and that "this progress has been actually slowed down by government intervention" 28 .

¡Once Richard Nixon occupied the White House Friedman took the reasoning to its logical, practical conclusion in a letter to Patrick Buchanan, a youthful conservative who was then a speechwriter for Nixon and that administration's informal liaison with the conservative movement. "The ultimate goal" of the administration in the area of schooling, said Friedman, ought to be "the complete elimination of governmental finance as well as operation, except perhaps in cases of extreme distress" ${ }^{29}$. So much for affirmative action. Needless to say, this also implied ceasing to interfere with de facto segregated schools as well as de jure, legally mandated segregation. The endurance over time of this critique was notable: Frank Meyer, a National Review senior staffer close to the libertarian position, had noted ten years previously that "while maintenance of equality before the law is a function of government", other issues such as "social customs and attitudes" were "not the concern of government". He therefore reached the type of conclusion that all conservatives peddled regularly: "segregation laws and integrating laws", Meyer claimed, "are equally wrong" ${ }^{30}$. Echoing similar feelings a few years later, Leonard Read -the head of the libertarian Foundation for Economic Education- lambasted the "application of coercion to education", and demanded a full withdrawal of state intervention because "universal education may be a worthy objective. But when coercion is applied, compelling universal attendance, it becomes necessary to «scrape the bottom of the barrel» to find teachers. The qualified teachers, Read thought, were in this way "watered down» by the unqualified, turning the trend away from excellence and toward mediocrity" 31 . Even though many libertarians ostensibly disagreed with the moral iniquities of segregation, by performing something of an exercise in selective dogmatism about individual liberty against government "coercion", their opposition to "big government" and "state interference" in the economic realm led them to oppose civil rights legislation as well. In the process,

27 "Property Law and Racial Discrimination", NIR, spring 1965, p. 48.

28 M. Friedman, There is No Such a Thing as a Free Lunch, LaSalle IL, Open Court, 1975, p. 216.

29 Milton Friedman to Patrick Buchanan, October 25, 1973, f. 11, box 22, Milton Friedman papers, Hoover Institute, Palo Alto CA, hereafter MF papers.

30 Frank Meyer to William Buckley, June 28, 1963, f. Negro Question, box 40 , WFB papers, emphasis in the original.

31 L. Read, "Look to the Stars", January 1967 pamphlet released by the Foundation for Economic Education, f. 2, box 23, Henry Regnery papers, Hoover Institution, Palo Alto, CA, hereafter HR papers. libertarian conservatives also appealed to a deep-seated streak of conservative grassroots resentment and mistrust of the federal authorities that civil rights legislation had done nothing but exacerbate. The fact that such legislation was in place precisely to preserve the individual rights of African-Americans seems to have gone about as unnoticed to libertarians as blunt white violence went for the National Review types ${ }^{32}$.

\section{Intra-conservative conflict and adjustment}

Despite the evident and enduring shared arguments against civil rights legislation, as American politics absorbed the right to legal racial equality as a given, the conservatives' approach to race evolved and created a degree of tension between the different strands within the movement. Religious beliefs led a number of Catholic conservative intellectuals and a few devout Protestant Southern politicians such as North Carolina representative Charles B. Deane to denounce segregation ${ }^{33}$. Garry Wills, a former Catholic seminarian, William F. Buckley's protégé and a man who would became one of the brightest conservative rising stars, realised by the late 1960s that conservative views on race either ignored the point of view of African-Americans, or merely portrayed them as a threat to the existing white-dominated Southern society. In a blunt letter of 1967 to Buckley, Wills asserted that conservatives only understood one South: the white South. "That is not enough anymore", he declared, "in fact only to understand one side -black or white- is not even to understand that" ${ }^{\prime 4}$. Nearly a decade earlier L. Brent Bozell, a radical conservative Catholic, Buckley's brother-in-law, National Review editor -and himself no shrinking violet when it came to accusing the "Negro leadership" of deliberately "singling out for violence" certain Southern cities- had vigorously contested the magazine's cavalier nonchalance in the face of what he regarded as a clear violation of both the United States Constitution and basic Christian principles. After all, National Review's support for legally mandated racial inequality was, Bozell correctly emphasised, particularly poignant from self-proclaimed strict constructionists and defenders of the Christian West ${ }^{35}$. Eventually, both Garry Wills and Bozell would leave the magazine, and in the case of Wills the conservative movement altogeth-

32 Interview with Milton Friedman, May 25, 2004, San Francisco; Edmund Opitz to Charles Halberg, June 15, 1964, f. 2, box 23, HR papers. Opitz was a senior staff member of the libertarian Foundation for Economic Education. For an evaluation of hostile grassroots views of the federal government and their relation to civil rights legislation cf. Horowitz, D. A. Horowitz, "White Southerners Alienation and Civil Rights, The Response to Corporate Liberalism", op . cit., pp. 173-200.

33 P. Allitt, Catholic Intellectuals and Conservative Politics in America 1950-1985, Ithaca, Cornell University Press, 1993, p. 115; T. Badger, op. cit., pp. 517-34.

34 J. B. Judis, William F. Buckley, Patron Saint of the Conservatives, op. cit., p. 130; Garry Wills to William F. Buckley, July 30, 1968, f. Garry Wills, box 57, WFB papers.

35 L. Brent Bozell, "The Lesson of Cambridge... and Salisbury. Was Violence Necessary?", NR, August 27, 1957; "Mr. Brent Bozell Dissents from the Views Expressed in the Editorial «Why the South Must Prevail»", ibidem, September 7, 1957, p. 209. 
er, amidst some acrimony, largely out of discontent with the position on race $^{36}$.

A rather different case was that of Harry V. Jaffa. Jaffa was an early disciple of Leo Strauss, a German emigreé who taught political philosophy at Chicago with a strong focus on the classics and a man who is frequently seen as the intellectual precursor of the neoconservatives. Yet, Jaffa occupied a peculiar space between the variant of policy-minded neoconservative that gathered around the pages of the journal The Public Interest and tended to focus on public policy and political theory rather than political philosophy on the one hand and the traditionalists of National Review on the other. The latter, being a lot less interested in policy proposals than in cultural and intellectual lucubration, lent themselves quite easily to the straussian angle of analysis. But Jaffa's influence during the period examined -mostly a rather quixotic attempt at recuperating the Declaration of Independence and the inheritance of Lincoln for the conservative cause- was very close to zero when it came to move the conservative position closer towards accepting the legitimacy of African-Americans' demands for equality; and it pales against the personal (to Bill Buckley at least) and ideological shockwaves provoked by the outbursts of Garry Wills' or L. Brent Bozell's also entirely unsuccessful attempts to mollify the unreconstructed racial views of either National Reviews or the white conservative Southerners during the period examined ${ }^{37}$.

In a similar vein, the hard core's ambivalence towards the plight of African-Americans also helped to increase the tension between traditionalists and those libertarians who believed that the Buckleyites only considered the rights of "Anglo-Saxons". Thus, some libertarians within the New Individualist Review had no qualms about denouncing what they regarded as the "mindless racism" of National Review conservatives, and the influence of what they saw as "segregationists and reactionaries" within organisations such as the Young Americans for Freedom (YAF), which was then the most important national youth organisation of the conservative movement with immense influence in the universities $^{38}$. This conflict would indeed play a crucial

36 J. B. Judis, William F. Buckley, Patron Saint of the Conservatives, op. cit., p. 130; Garry Wills to William F. Buckley, July 30, 1968, f. Garry Wills, box 57, WFB papers.

37 Harry Jaffa encountered considerable difficulties to reconcile his own benign views about the American liberal (in the classical, $19^{\text {th }}$ century sense) tradition with both National Review's outright hostility and Strauss' Strauss' apparent disinterest and conflicted views on American eminently modern culture placed. This placed some significant limits on both Strauss' and Jaffa's direct influence over the early conservative movement and may explain the notable absence of references to the former's work in National Review's abundant internal correspondence or in either William F. Buckley's and William Rusher's archives as well. At any rate a quite superb assessment of the straussians approach to race may be found in R. H. King "Rights and Slavery, Race and Racism: Leo Strauss, The Straussians, and The American Dilemma", Modern Intellectual History, 5, 1, 2008, pp. 55-82. For an assessment of the impact of Bozell and Wills disagreements cf. ff. 36 above.

38 R. Hamowy, "National Review, Criticism and Reply", NIR, November 1961; "Editorial, The Cry of Power, Black, White and Polist", Right and Left, Autumn 1968, p.11; [Untitled and undated press cutting] Stanford Daily News, f. Strom Thurmond, box 256, WFB papers; Interview with Richard Ebeling, November 20, 2005, Swindon, UK. part in precipitating the near implosion of the conservative movement's youth wing. In December 1969, the entire California branch of YAF, as well as the most active parts of the New Jersey, New York and Pennsylvania state organisations threatened a collective walkout $t^{39}$. According to David Friedman, Milton Friedman's son and then a leading young libertarian, the event would have meant the loss of the "bigger associations, with the most active leaders" 40 . Eventually, the California state organisation was disbanded, and the issue even resurfaced in the mainstream press -where it had already been something of a recurrent source of embarrassment for the movement ${ }^{41}$. Tensions about race had the power to intensify both the petty power struggles within the YAF leadership and, most importantly, the general strain between traditionalist conservatism and radical libertarianism in the broadest sense $\mathrm{e}^{42}$.

As echoed in the New Individualist Review, many young libertarian within YAF objected to what they saw as National Review's devotion to "a polite form of white supremacy". Others, like a young Floridian activist, voiced disgust at the perceived "incorporation of racists, know-nothings and anti-Semites" into the movement ${ }^{43}$. As early as 1964, some libertarian YAFers deplored their organisation's self-identification as "conservative", and genuinely (but mistakenly) believed that YAF's views were based "largely on the concepts of pre-1880 English liberalism. Namely: freedom, rationality" and "the perfectibility of all men" 44 . In fact, the conservative youth was even more divided than its elders. For instance as some activists grew increasingly uncomfortable with their elders racial outlook YAF's own organ The New Guard labelled Strom Thurmond "a man of courage" and trumpeted how the senator "has been one of our most outspoken supporters". The New Guard was also not afraid of reproducing National Review style support for the white conservative South such as labelling civil rights protests "unchristian" and "a threat to our system of law", or of even claiming that the main "problem" with the African-American was that "on average, he

3 An excellent firsthand account of YAF's travails by one of its architects in M. Liebman, Coming Out Conservative, San Francisco, Chronicle Books, 1992, particularly pp. 145-48, 150-55.

40 David Friedman to Frank Meyer, December 1, 1969, f. YAF, box 66, WFB papers.

41 "Seeds of Schism on the Right" The New Republic, March 5, 1962 ; "Internal Row Threatens to Split Young Rightists", San Francisco Sunday Examiner \& Chronicle, October 5, 1969; "Campus Conservatives, Where Are they Now?", Mademoiselle, August 1963; David Friedman to Frank Meyer, December 1, 1969, f. YAF, box 66, WFB papers; A. Crawford, Thunder on the Right: The "New Right" and the Politics of Resentment, New York: Pantheon Books, 1980, p. 97; Diamond, Roads to Dominion, op cit. pp. 124-25.

42 Interview with Lee Edwards, August 15, 2005, Washington DC, Morton Blackwell, August 29, 2005, Washington DC; Interview with David Keene, August 24, 2005, Washington DC.

43 R. Hamowy, op. cit., Hanowy's article offers an overview of the ideological tensions between "libertarian-liberal", "rationalists", "traditionalists", and "authoritarians". Cf. also J. O'Connell, "The New Conservatism", ibidem, spring, 1962, p. 17-22; Stephen Mare Slepin to William F. Buckley, May 24, 1964, f. YAF, box 33, WFB papers, Robert Bauman to Buckley, July 6, 1964, ibidem.

44 J. L. Donne, "The New Ideology", The New Guard, June 1964; Interview with David Keene; Interview with Morton Blackwell. 
lacks a desire to improve himself and lacks a willingness to discipline himself to this end" ${ }^{\prime 4}$.

Yet, amidst all this tension, by the early 1970s the movement's intellectual leadership had come to understand the need for a much softer approach to civil rights. In 1970, National Review lent its pages to Vincent S. Baker, an African-American conservative and early outlier of the small band of black conservatives that emerged from the late 1970s onwards and who was keen to remind his fellow travellers that America's blacks "wanted in" to the conservative movement and the Republican party ${ }^{46}$. Baker, much like the white conservatives who deviated from the rather intransigent stand clearly marked by National Review such as Harry Jaffa, L. Brent Bozell and Garry Wills, miserably failed at the time. Eventually, however, some conservative operatives came to regret, and recanted from, their previous opposition to civil rights legislation ${ }^{47}$. As early as 1968 National Review, although still concluding that full desegregation was a near-impossibility, celebrated the limited success of a locally managed experiment in integration in Shaker (Ohio). Jeffrey Bell, a young conservative operative who worked for the Nixon campaign is quite illustrative of this shift: "I was never a racist or a segregationist, but at one time I questioned the need to have national laws on things like public accommodations. I later realised that you did need that" ${ }^{\prime 8}$. Eventually many, indeed virtually all, libertarians declared their support for civil rights legislation, but continued to oppose affirmative action generally and racial quotas in particular ${ }^{49}$. In 1970 even William F. Buckley applauded the judicial decision calling upon Governor Kirk of Florida, then engaged in a much publicised attempt to prevent the implementation of federally mandated civil rights legislation, to obey the law, and defined Kirk's racial sabre-rattling deploying language not all that different from the terms hitherto dedicated to civil rights activists when he defined it as "grandstanding against the law" 50 .

This should not be equated with support for integration and should be read as an attempt to adjust opposition to civil rights to new political circumstances that, again, closely followed the strategy of those Southern conservative politicians who also happened to be the key political wing of a then still fundamentally intellectual movement. Aware that diehard opposition led to a

45 "A Man of Courage", The New Guard, October 1964; A.C. Brownfield, "Disrespect for Law and Order", ibidem, December 1964; G. Stigler, "The Problem of the Negro", ibidem, December 1965. Stigler was a leading libertarian academic in the same league as Milton Friedman and Friedrich von Hayek, and was also a founding member of the famous Mont Pelerin Society.

46 V. S. Barker, "Black Americans Want In", NR, August 25, 1970. For an interesting examination of this small band of African-American conservatives who would gain some prominence later on but quite outside the scope of this article cf. A. D. Dillard, Guess Who's Coming to dinner now? Multicultural Conservatism in America, New York, New York University Press, 2001.

47 Interview with Morton Blackwell; Interview with David Keene; Interview with Lee Edwards.

48 S. Friedman, "The Ludlow Precedent", NR., July 16, 1968; Jeffrey Bell, August 29, 2005, Washington DC.

49 Interview with Michael Baroody, September 6, 2005, Washington DC; Interview with Leonard Liggio, May 18, 2004, Fairfax, VA.

50 W. F. Buckley, "Repression USA", NR, April 7, 1970. political cul-de-sac and of the opportunities afforded by the presidency of Richard Nixon, the Southern congressional caucus was by then shifting away from defense of de jure segregation and towards supporting de facto segregation on the right side of the law ${ }^{51}$. James Jackson Kilpatrick, for instance, was quite clear on the matter: although it took him sixteen years after the Brown decision in which the Supreme Court of the United Sates mandated the end of racially segregated schooling, he eventually recognised that "segregation is dead as a permissible legal device". However, he still believed that it nevertheless survived "in fact and human nature" and therefore beyond the scope for useful or moral government intervention. Kilpatrick then proceeded to peddle the typical Southern discourse that would also be reproduced by the rest of the conservative movement, arguing that "the constitution [and Brown] does not require affirmative measures to undo de facto separation", and concluded by expressing his "own conviction" that "the problems will be tolerably resolved through the return to old principles of community" 52 . Or, in other words, leaving the mater of race to the same local communities then engulfed in violence and unrest and hitherto responsible for enforcing -with considerable violenceAfrican-American subordination.

As the conservative movement, led by its southern wing, attuned its position towards the racial issue throughout the late 1960s and early 1970s, their adjustment began to receive support, albeit indirectly, from rather surprising quarters. A group of intellectuals, politicians and social scientists deeply embedded in the academic world and the intellectual circles of New York City as well as with Democratic leaning politics, which had hitherto provided staunch support for the liberal-progressive consensus, progressively turned against what they perceived to be the excesses of the sixties -not just on racial issues- and the failures of Lyndon Johnson's Great Society. In contrast with the traditionalists of National Review who quite consciously aligned themselves within a broader, transatlantic conservative tradition with strong anti-modern undertones and therefore of difficult translation into American political language, the neocons, to a man, set themselves within the American (therefore very much modern) political tradition and quite deliberately aside from the traditionalists which the neoconservatives perceived as excessively "European" and therefore "alien" to the American environment of the 1960's and 70's, as was explicitly indicated to anyone willing to listen by the two "godfathers" of this epistemic community: Irving Kristol and Norman Podhoretz ${ }^{53}$. As in the case of the neoliberals,

51 For a detailed analysis of the "northernisation" of the Southern conservatives cf. D. Sarias Rodríguez "Richard Nixon, las primarias republicanas de 1968 y la modernización del conservadurismo sureño", op.cit.; the best evaluation of the shifting patterns of racial segregation on the ground remains M. Lassiter, The Silent Majority, Suburban Politics in the Sunbelt South, op. cit.

52 J. J. Kilpatrick, "Back to Segregation by Order of the Courts", NR, June 16, 1970.

53 I. Kristol Neoconservatism, The Autobiography of an Idea, New York, The Free Press, 1995, pp. 377-378; Interview with N. Podhoretz, June 28, 2004, telephone. The neoconservative community is sometimes and quite mistakenly equated, as a group, with "the 
this difference with the traditionalist ideological aloofness goes a good way to explain both the neoconservatives' propensity to engage, unlike traditionalists', in actual policy proposals and their success in turning both their own ideas and the policies they proposed into acceptable options within the American political and policy-making mainstream.

Dissatisfaction with civil rights activism - particularly as it affected the educational world- would be a prime force propelling these men, later to be known as "neoconservatives", towards the right. These mostly Jewish intellectuals' disenchantment with liberalism was reaching a peak the same year that Richard Nixon arrived to the White House. That year, the growing tension between the (mainly Jewish) teachers and the (mostly black) parents and students of the schools in the New York neighbourhood of Ocean Hill and Brownsville led to a teachers' strike that effectively signalled the end of the informal pro-civil rights alliance between the Jewish and black communities ${ }^{54}$. The distance separating black activists and Jewish intellectuals had been increasing for some time: in 1963 Norman Podhoretz, then a prominent "radical" (meaning leftwing) New York intellectual and editor of the prestigious Jewish journal Commentary, published an article in which he questioned progressive "pieties" on the race issue. Drawing upon his own experiences of growing up in a racially-mixed Brooklyn neighbourhood, Podhoretz observed that according to liberal-progressives, "Negroes were supposed to be persecuted", and yet, "such evidence of the senses as comes from being repeatedly beaten up, robbed, and in general hated, terrorized, and humiliated" seemed to indicate that "it was the Negroes who were doing the only persecuting I knew about" ${ }^{55}$. During the run up towards the 1972 election, Podhoretz would culminate his apostasy from the liberal-Democratic fold by unleashing a campaign in support of the Nixon candidacy in Commentary

straussians" or followers of Leo Strauss. Of course, Strauss did shape some aspects within the academic disposition of some neoconservatives and helped neoconservatism garner cohesion as an epistemic community; but the very nature of Strauss' highly abstract work and interests placed limits on anything beyond that -relevant as it indeed is. Thus, neither Norman Podhoretz nor Sydney Hook nor most of the social scientists who gathered around the Public Interest, for instance, had much to do with Strauss and at any rate, quite regardless of the academic and ideological influence held by his work -detectable in, say, Irving Kristol's fixation with the classical notion of virtu - these early neoconservatives, enjoyed, in flagrant contradiction with Strauss' own outlook, the very much modern policy-making fray with considerable gusto and fully armed with the rather un-straussian tools of modern social sciences. At any rate, a quite illuminating, detailed and, tellingly enough, mostly focused on followers of Strauss working years later than the period covered in this pages, may be found in R. H. King "Rights and Slavery, Race and Racism: Leo Strauss, The Straussians, and The American Dilemma", op. cit. For a brief assessment of neoconservatism along lines remarkably similar to those of this article cf. R. H. King, "The Struggle Against Equality: Conservative Intellectuals in The Civil Rights Era", op. cit., The author acknowledges again Reviewer \#2's suggestion to consult King's work for this article.

54 J. Ehrman, op. cit., pp. 159-60; J. Heilbrunn, op.cit., p. 85.

55 N. Podhoretz, "My Negro Problem - And Ours", Commentary, February 1963, as reprinted in idem, Commentary Reader, London, Rupert Hart-Davis, 1968, pp. 376-77. For Podhoretz's account of his reactions to the Civil Rights movement, cf. idem., Breaking Ranks, New York, 1979, pp. 129, 134-35. the up until then progressive leaning journal that he directed $^{56}$.

Another case in point is provided by Daniel Patrick Moynihan, a well known Harvard academic and Kennedy supporter then working within the Johnson administration. In 1965 Moynihan triggered the fury of civil rights leaders while jumping to nationwide prominence as a result of penning a Department of Labor study which seemed to suggest that the main root of African-American socio-economic problems lay in the so-called "collapse of the black family" -which African American leaders correctly interpreted as "blaming the victim" In the same year, a group of liberal intellectuals and academics, including Moynihan, gathered around the pages of a new journal, The Public Interest, which aimed to discuss issues of public policy -including the problems of "the Negro American"58. By 1968 the journal had become an immensely prestigious source of comment on the limitations of government intervention and the iniquities of the Great Society, and in the following year Moynihan himself could be found working within the Nixon White House and publicly doubting the efficacy of 1960 s civil rights policy ${ }^{59}$. A year later, a memorandum from Moynihan to the president which advocated a period of "benign neglect" on civil rights issues was leaked, infuriating African-American leaders. At around the same time Sydney Hook, yet another formerly liberal intellectual close to the Public Interest circle, was also actively supporting the White House out of concern about racial quotas in the universities and campus violence $^{60}$.

Throughout Nixon's first term in office, the so-called "neoconservatives" became progressively embedded within the administration -which in turn was widely seen as increasingly close to conservatives generally and the white South in particular ${ }^{61}$. While Moynihan and Hook actively collaborated with the administration from the inside, Ben Wattenberg and Richard Scammon, two other Democrats from the Kennedy-Johnson administrations, published The Real Majority, an analysis of former Alabama Governor and segregationist's darling George Wallace's campaigns up to 1968 focused on what they called the "social issue". The book evaluated the first electoral stirrings of what has come to be known as the "backlash" against the permissiveness of the 1960s, and recommended a political message centred on the "law and order" issue while emphasising the growing link be-

56 Interview with Norman Podhoretz, June 28, 2004, telephone. For an overview of the neoconservative's motivations cf. D. Sarias Rodriguez, "The Other 1960s: Re-Assessing the Enduring Influence of Neoconservatism", op. cit., pp. 271-296.

5 G. Hodgson, op. cit., pp. 138-39, 141

58 N. Glazer, “The Negro American", The Public Interest, Spring 1966, pp. 109-15, hereafter $P I$.

59 D. P. Moynihan, op. cit., pp. 198-209, especially pp. 208-209; "What is the Public Interest", PI, Summer 1966, p. 3; R. J. Whalen, Catch the Falling Flag: A Republican's Challenge to His Party, Boston, Houghton Mifflin, 1972, p. 38.

60 G. Hodgson, Gentleman from New York, pp. 157-59; Joseph Baroody memorandum to Charles Colson, October 20, 1970, f. Campus Unrest, box 44, Charles W. Colson Materials, Richard Nixon Presidential Materials, National Archives, College Park ML, hereafter CC papers.

61 D. Sarias Rodriguez, "The Other 1960s" op. cit., pp. 271-296. 
tween public disturbances and civil rights activism in the public mind. Even before the book came out, Wattenberg could already be found operating on the periphery of the conservative movement as a collaborator with the American Enterprise Institute, a think-tank that had been an integral part of the movement since the $1950 \mathrm{~s}^{62}$.

Thus, to the delight of conservatives, a significant group of formerly Democratic and still mostly perceived-as-liberal intellectuals was openly reproducing conservative, sometimes segregationist tropes, questioning what they saw as the "excesses" of the civil rights movement. These included familiar euphemisms, such as the appropriate role of "state and local action", or whether desegregating schools was "less important than getting better schools"63. To be sure, the role of race relations in the development of what would later be called neoconservatism should not be overemphasised and it needs to be located within a larger preoccupation with what Moynihan labelled "a national nervous breackdown" involving the Vietnam war, the counterculture and what they perceived as the failures of the Great Society ${ }^{64}$. Also, as with conservatives generally, in most cases these intellectuals' evolving critique of the civil rights movement did not preclude opposition to, and indeed had little to do with, de jure segregation itself, but stemmed largely from hostility towards the establishment of racial quotas (particularly in the universities), alarm about violence (specially in the campus), and a general disenchantment with the Great Society that mirrored the original hostility of the conservative movement but was qualitatively different from it. Yet, the neocons' arguments against affirmative action had a way of coinciding with and lending gravitas to similar anti-civil rights views expressed by other conservative sub-families. For instance, predating the protestations of neoconservatives such as Irving Kristol and Norman Podhoretz, the classical liberal Milton Friedman had stated the case in a letter to William F. Buckley nearly ten years earlier. "The fundamental mission of the university", Friedman asserted, "is to provide instruction and the opportunity for the search for understanding", and nothing else -no matter how "admirable and desirable" objectives such as "clearing slums" or racial equality might be. That was why libertarians also "fought against the idea that the universities should be agencies of social change" through, for instance, racial quotas ${ }^{65}$. Little surprise then, when Garry Wills, the former Buckleyite then in the process of becoming a liberal out of,

62 R. Scammon and B. Wattenberg, The Real Majority, New York, Coward, McCann \& Geoghegan, 1970, pp. 35-44, 185-99; R. Mason, Richard Nixon and the Quest for a New Majority, Chapel Hill NC, University of North Carolina Press, 2004, p. 83; Interview with Melvin Laird, May 16, 2006, telephone. It should be noted that some historians have contested the backlash thesis, cf. M. Lassiter, The Silent Majority, Suburban Politics in the Sunbelt South op. cit.; and T. J. Sugrue, The Origins of the Urban Crisis, Race and Inequality in Postwar Detroit, Princeton, Princeton University Press, 1996.

63 N. Glazer, "The Negro American”, op. cit., pp. 108, 114.

64 As quoted in Robert Mason, Richard Nixon and the Quest for a New Majority op. cit., p. 22; cf. also R. Scammon and B. Wattenberg, The Real Majority, op. cit., pp. 238-40, 261.

65 Milton Friedman to William F. Buckley, April 26, 1964, f. 13, box 22, Milton Friedman papers, Hoover Institute, Palo Alto CA, hereafter MF papers, HI. among other issues, frustration with the conservative stand on race, and who was a extraordinarily perceptive observer, was quick to identify the triangulation between the neoconservatives move away from liberal-progressivism, the conservatives evolution towards new forms of opposition to federally sponsored racial equality legislation and Richard Nixon's "law and order" electoral strategy $^{66}$.

The emergence of the neoconservative critique dramatised in a quite public manner the increasing erosion of support for further affirmative action and remarkable success of the modified anti-civil rights discourse that had emerged from the conservative movement. The neocons did not question civil rights enforcement out of previously held conservative views, or attachment to a segregated way of life: it was the perceived iniquities 1960 s civil rights policies that helped to push them towards the right. On the other hand, at this time, the intellectuals and activists of the conservative movement tended to consider these intellectuals as ad-hoc liberal allies against the excesses of "radicalism" $"$. Richard Scammon and Ben Wattenberg, two influential early neoconservatives, certainly believed that civil rights-related violence and the consequent changing perception of the movement was "at the root" of the emergence of what they euphemistically termed the "social issue". In 1970, and employing language which echoed that of the buckleyites at National Review, Sydney Hook would go as far as to equate the "benighted" Southern "racists" with the leftwing "homicidal idealists of Madison, Boston, Rochester and elsewhere" ${ }^{68}$. Increasingly, these intellectuals' assaults upon "bureaucratic inefficiency" and the need to preserve "law and order" differed less and less from the typical line peddled by conservatives during the previous decades ${ }^{69}$.

Needless to say, Southern conservatives and conservatism generally, greatly benefited from the emergence of this prestigious critique of civil rights. Although not motivated by support for segregation, strict constructionism, or even a fundamental disagreement with state interventionism per se, neoconservatives had the effect of sustaining and reinforcing the white Southerners' conservative agenda. This impact was all the more significant because unlike most conservatives, men like Daniel Patrick Moynihan, John Podhoretz and Sidney Hook had operated within the very liberal community that had originally helped to create and to manage the post-war liberal consensus, only to discover what they saw as the limitations of government programmes

66 G. Wills, Nixon Agonistes: The Crisis Of the Self-Made Man, New York, Mentor Book, 1971, pp. XX.

67 Interview with Jeffrey Bell; Interview with Morton Blackwell; Interview with William F. Buckley, July 25, 2005, New York City; Interview with David Keene.

68 Scammon, The Real Majority, op. cit., p. 42; S. Hook, "Terror on Campus, An Indictment", New York Times, October 22, 1970, hereafter NYT. Predictably enough, Special Assistant to the President Colson enthusiastically suggested that the article "would be worth some wide circulation", Memorandum from Charles Colson to Pat Buchanan, Lyn Nofziger, Bob Finch, Larry Higby, Jeb Magruder and Jim Keog, October 24, 1970, f. Sydney Hook Centre for Rational Alternatives, box 72, CC papers.

69 Cf. R. J. Dwyer, "I know about the Negroes and the Poor", $N R$, December $17,1963$. 
which, according to an article appeared in the Public Interest, the main neoconservative organ, and echoing $\mathrm{Na}$ tional Review type rhetoric, consisted of having an elite of "middle-class civil servants hire upper-class students to use lower-class Negroes" against the "existing local political systems" ${ }^{\prime 72}$.

\section{Conclusions}

Since the mid-1950s, the hard core had developed a close relationship with Southern conservatives, one in which the former provided some form of intellectual legitimacy and obtained in return a relatively influential political arm, as well as the broader constituency that came with it. Nevertheless the price of this collaboration for Buckleyites was the perception that they were plainly racist, a perception which was underlined by the heightened tension with other sub-families within the broader con- servative movement that were less comfortable with the hard core's stance. Of course the conservative's racial views were not static. Over time, they evolved towards more moderate, pragmatic positions that accepted some of the legal gains of the civil rights movement. But up to Nixon presidency the conservative community never seriously held any pretensions of acquiring substantial black support. Finally, the evolution of the conservative movement was also largely reproduced and supported by a number formerly liberal-progressive intellectuals, soon to be known as "neoconservatives" who seemingly followed Buckley's example but coming from a very different background that lend enhanced credibility to a renewed form of opposition against further civil rights advances that also denied any racist undertones. Consistently, all the aforementioned intellectuals expressed open indifference towards de facto segregation and aimed to paralyse any further measures designed to promote racial equality ${ }^{73}$.

\section{Sources}

\section{Interviews}

Michael Baroody, September 6, 2005, Washington DC. Jeffrey Bell, August 29, 2005, Washington DC. Morton Blackwell, August 29, 2005, Washington DC. William F. Buckley, July 25, 2005, New York City. Richard Ebeling, November 20, 2005, Swindon, UK. Lee Edwards, August 15, 2005, Washington DC.

Milton Friedman, May 25, 2004, San Francisco, CA. Melvin Laird, May 16, 2006, telephone.

Leonard Liggio, May 18, 2004, Fairfax, VA.

Howard Phillips, September 7 2005, Washington DC.

Norman Podhoretz, June 28, 2004, telephone.

\section{Archives}

William F. Buckley Jr. papers, Manuscripts and Archives, Yale University Library, New Haven, CT.

Charles W. Colson Materials, Richard Nixon Presidential Materials, National Archives, College Park ML. Milton Friedman papers, Hoover Institute, Palo Alto CA.

Group Research Records, Rare Book and Manuscript Library, Columbia University Library, New York City.

Marvin Liebman papers, Hoover Institution, Palo Alto, CA.

Henry Regnery papers, Hoover Institution, Palo Alto, CA.

\section{Cited bibliography}

-, “A Clarification”, National Review, August 31, 1957, p. 199.

-, “A Man of Courage", The New Guard, October 1964.

-, “Campus Conservatives, Where Are they Now?”, Mademoiselle, August 1963.

-, "Editorial Advisors", Modern Age, vol. 1, no. 1, summer 1957.

-, "Editorial Advisors", New Individualist Review, April 1961.

-, "Editorial, The Cry of Power, Black, White and Polist", Right and Left, Autumn 1968, p.11.

-, "Internal Row Threatens to Split Young Rightists", San Francisco Sunday Examiner \& Chronicle, October 5, 1969.

-, "Nixon Seeks Conference with Hoover over Disorders", Human Events, September 21, 1968.

-, "Roots of Liberal Complacency", National Review, June 8, 1957.

-, "Seeds of Schism on the Right", The New Republic, March 5, 1962.

-, "Semantics vs. the South", Human Events, February 18, 1960. 
-, “Summer, 1968 - Riot or Rebellion?”, Washington Report, April 15, 1967.

-, "The Rhodesian Calumny", New Individualist Review, winter, 1968;

-, “The South's Travail”, National Review Bulletin, March 14, 1960.

-, "Letter from Congo", National Review, March 25, 1961.

-, "Mr. Brent Bozell Dissents from the Views Expressed in the Editorial «Why the South Must Prevail»", National Review, September 7, 1957, p. 209.

-, "Mardian, The Team Player, The Loyalist in Hiding", Washington Post, July 8, 1973.

-, "Property Law and Racial Discrimination", New Individualist Review, spring 1965, p. 48.

-, "Why the South Must Prevail", National Review, July 27, 1957, p.149.

Allitt, P., Catholic Intellectuals and Conservative Politics in America 1950-1985, Ithaca, Cornell University Press, 1993.

Badger, T., "Southerners Who Refused to Sign the Southern Manifesto", Historical Journal 42, 1999, pp. 517-34.

Barker, V. S., "Black Americans Want In", National Review, August 25, 1970.

Bartley, N. V. and Graham, H., Southern Politics and the Second Reconstruction, Baltimore, Johns Hopkins University Press, 1975.

Bartley, N.V., The New South, 1945-1980, The Story of the South's Modernization, Baton Rouge, Louisiana State University Press, 1995.

Bass J. and Thompson, M.W., Ol'Strom, The Unauthorised Biography of Strom Thurmond Marietta GA, Longstreet, 1998.

Bethel, P. D., "Black Power and Red Cuba", National Review, September 2, 1968.

Black, E. and Black, M., The Rise of Southern Republicans, Cambridge MA, Harvard University Press, 2002.

Bosanquet, N., After the New Right, London, Heinemann, 1983.

Bozell, L. B., "The Lesson of Cambridge... and Salisbury. Was Violence Necessary?”, National Review, August $27,1957$.

Brownfield, A. C., "Disrespect for Law and Order”, The New Guard, December 1964.

Buckley, W. F., Miles Gone By, A Literary Autobiography, Washington DC, Regnery, 2004.

Burns, J., Goddess of the Market, Ayn Rand and the American Right, Oxford, Oxford University Press, 2009.

Carter, D., The Politics of Rage, George Wallace, The Origins of New Conservatism and The Transformation of American Politics, New York, Simon \& Schuster, 1995.

Chambers, W., "Big Sister is Watching You", National Review, December 28, 1957.

Crawford, A., Thunder on the Right: The "New Right" and the Politics of Resentment, New York, Pantheon Books, 1980.

Cockett, R., Thinking the Unthinkable: Think Tanks and the Economic Counter-Revolution, London, HarperCollins, 1994.

Cohodas, N., Strom Thurmond and The Politics of Southern Change, New York, Simon \& Schuster, 1993.

Diamond, S., Roads to Dominion, Right-Wing Movements and Political Power in the United States, New York, Guilford Publications, 1995.

Dillard, A. D., Guess Who's Coming to dinner now? Multicultural Conservatism in America, New York, New York University Press, 2001.

Duignan, P. and Gann, L. H., "White and Black in Africa", National Review, January 28, 1961.

Dwyer, R. J., "I know about the Negroes and the Poor", National Review, December 17, 1963.

Edwards, L., The Conservative Revolution, The Movement that Remade America, New York, Free Press, 1999.

Ehrman, J., The Rise of Neoconservatism, New Haven, Yale University Press, 1995.

Friedman M., There is No Such a Thing as a Free Lunch, LaSalle IL, Open Court, 1975.

Friedman, S., "The Ludlow Precedent", National Review., July 16, 1968.

Gerson, M., The Neoconservative Vision, From the Cold War to the Culture Wars, Lanham ML, Madison Books, 1996.

Glazer, N., "The Negro American", The Public Interest, Spring 1966, pp. 109-15, "What is the Public Interest", Public Interest, Summer 1966, p. 3.

Halper S. A. and Clarke, J., America Alone, The Neo-Conservatives and the Global Order, Cambridge, Cambridge University Press, 2004.

Hamowy, R., "National Review, Criticism and Reply", New Individualist Review, November 1961.

Hardisty, J., Mobilizing Resentment, Conservative Resurgence from the John Birch Society to the Promise Keepers, Boston, Beacon Press, 1999.

Hayek, F., The Constitution of Liberty, Chicaco, Chicago University Press, 1962.

Heilbrunn, J., They Knew They Were Right, The Rise of the Neocons, New York, Anchor Books, 2009.

Helms, J., "Falsehoods About the South", Human Events, March 11, 1962.

Hijiya, J. A., "The Conservative 1960s", Journal of American Studies, 37, no. 2, 2003, pp. 201-27.

Himmelstein, J. L., To the Right, The Transformation of American Conservatism, Berkeley, University of California Press, 1990 , pp. $49-60$.

Hodgson, G., The World Turned Right Side Up, A History of the Conservative Ascendancy in America, Boston, Houghton Mifflin, 1996, pp. 44-45, 51.

-, The Gentleman from New York, Daniel Patrick Moynihan, A Biography, Boston, Houghton Mifflin, 2000.

Hook, S., “Terror on Campus, An Indictment”, New York Times, October 22, 1970.

Horowitz, D. A., "White Southerners Alienation and Civil Rights, The Response to Corporate Liberalism", Journal of Southern History 54, May 1988, pp.173-200.

Huxley, E., "The Castle of Apartheid", National Review, August 27, 1968.

Judis, J. B., William F. Buckley, Patron Saint of the Conservatives, New York, Simon \& Schuster, 1988.

Kilpatrick, J. J., "Back to Segregation by Order of the Courts", National Review, June 16, 1970.

-, “Civil Rights and Legal Wrongs", National Review, September, 10, 1963.

King, R. H., "The Struggle Against Equality: Conservative Intellectuals in The Civil Rights Era", in Ted Ownby, The Role of ideas in The Civil Rights South, Jackson, Mississippi University Press, 2002, pp. 113-136. 
-, "Rights and Slavery, Race and Racism: Leo Strauss, The Straussians, and The American Dilemma", Modern Intellectual History, 5, 1 (2008), pp. 55-82.

Kristol, I., Neoconservatism: The Autobiography of an Idea, New York, The Free Press, 1995.

Lassiter, M., The Silent Majority, Suburban Politics in the Sunbelt South, Princeton, Princeton University Press, 2006.

Liebman, M., Coming Out Conservative, San Francisco, Chronicle Books, 1992.

Mason, R., Richard Nixon and the Quest for a New Majority, Chapel Hill NC, University of North Carolina Press, 2004.

Micklethwait, J. and Wooldridge, A., The Right Nation, Conservative Power in America, New York, Penguin, 2004.

Molnar, T., "South Africa Reconsidered", National Review, winter 1966.

Moynihan D. P., Coping: Essays on the Practice of Government, New York, Random House, 1973.

Murphy, P. B., The Rebuke of Histor. The Southern Agrarians and American Conservative Thought, Chapel Hill, University of South Carolina Press, 2001.

Nash, G. H., The Conservative Intellectual Movement in America Since 1945, Wilmington DE, Intercollegiate Studies Institute, 1998.

O’Connell, J., “The New Conservatism”, New Individualist Review, spring, 1962, p.17-22.

Podhoretz, N., Commentary Reader, London, Rupert Hart-Davis, 1968.

-, Breaking Ranks, New York, 1979.

Reichley, A. J., Conservatives in an Age of Change, The Nixon and Ford Administration, Washington DC, Brookings Institution, 1981.

Reinhard, D. W., The Republican Right Since 1945, Lexington KY, University Press of Kentucky, 1983.

Sanders, R., "Rassling a Governor, Defiance, Desegregation, Claude Kirk, and the Politics of Richard Nixon's Southern Strategy", Florida Historical Quarterly, 80, no. 3, 2002.

Sarias Rodriguez, D., "The Other 1960s: Re-Assessing the Enduring Influence of Neoconservatism", Revista de Estudios Norteamericanos N. 23, 2019, pp. 271-296.

-, “«We Are All Europeans»: Towards a Cosmopolitan Understanding of the American Traditionalist Right” en Daniel Scroop and Andrew Heath (eds), Transatlantic Social Politics 1800-Present, New York, Palgrave, 2014, pp. 213-234.

-, "Richard Nixon, las primarias republicanas de 1968 y la modernización del conservadurismo sureño", Historia y Política, Ideas, Procesos y Movimientos sociales, № 20, 2008, 293-312.

Scammon R. and Wattenberg, B., The Real Majority, New York, Coward, McCann \& Geoghegan, 1970, pp. 35-44, 185-99.

Scanlon, S., "The Conservative Lobby and Nixon's «Peace with Honor» in Vietnam", Journal of American Studies 43, no. 2, 2009, pp. 255-76.

Schaller, M., Right Turn, American Life in the Reagan-Bush Era, New York, Oxford University Press, 2007.

Schmidt, C.W., "Beyond Backlash: Conservatism and the Civil Rights Movement", American Journal of Legal History, $56,2016$.

Steinfels, P., The Neoconservatives, The Men Who Are Changing America's Politics, New York, Simon \& Schuster, 1979.

Stigler, G., "The Problem of the Negro", The New Guard, December 1965.

Sugrue, T. J., The Origins of the Urban Crisis, Race and Inequality in Postwar Detroit, Princeton, Princeton University Press, 1996.

Van Den Haag, E., “Intelligence or Prejudice?”, National Review, December 1, 1964.

Weaver, R., "On Setting the Clock Right", National Review, October 12, 1957.

-, "As the South Sees it", National Review, February 13, 1960.

Whalen, R. J., "As the South Sees it", National Review, February 13, 1969.

-, Catch the Falling Flag: A Republican's Challenge to His Party, Boston, Houghton Mifflin, 1972.

Wildavsky, A., "The Empty-Head Blues, Black Rebellion and White Reaction”, Public Interest, Spring 1968, p. 3.

Wills, G., Nixon Agonistes: The Crisis Of the Self-Made Man, New York, Mentor Book, 1971. 
